\title{
Pemantauan Kesehatan Gizi Ibu Hamil Dilihat dari Pertambahan Berat Badan dan Pengukuran Lingkar Lengan Atas (LILA) Berbasis E-Digital
}

\author{
Yuli Wahyuni ${ }^{1}$, Akbar Sugih Miftahul Huda ${ }^{2}$ \\ Sekolah Vokasi, Universitas Pakuan, Bogor, Indonesia \\ Corresponding Author: yuli_wahyuni@unpak.ac.id
}

Article history: received 30 September 2018; revised 10 Desember 2018; accepted 21 Desember 2018

\begin{abstract}
Abstrak
Pengukuran LILA pada kelompok wanita usia subur (WUS) baik ibu hamil merupakan salah satu cara deteksi dini yang mudah dan dapat dilaksanakan oleh masyarakat awam, untuk mengetahui kelompok beresiko KEK. KEK merupakan keadaan dimana ibu penderita kekurangan makanan yang berlangsung menahun (kronis) yang mengakibatkan timbulnya gangguan kesehatan pada ibu. Selama ini sistem pencatatan ibu hamil di posyandu masih menggunakan sistem manual yaitu data ibu hamil yang diperoleh masih menggunakan kalkulator untuk mengetahui kondisi kategori ibu hamil selain itu data yang digunakan untuk mengarsif data masih menggunakan buku dan Microsoft excel hal ini sangat menyulitkan petugas posyandu apabila mau mencari data ibu hamil dan kesulitan dalam melakukan laporan karena data tidak disimpan dengan baik. Data seperti ini sangat rawan kehilangan data dan kerusakan data apabila suatu waktu dibutuhkan lagi. Penelitian ini telah berhasil dilakukan yang dapat menyimpan data pada cloud berupa data-data ibu hamil berupa tambahan data pasien, edit data, hapus data dan pencarian data selain itu pada tampilan website dapat menampilkan halaman login, dashboard, data interpretasi, halaman data pasien, halaman perhitungan data pasien, halaman edit data pasien.
\end{abstract}

Kata Kunci : gizi, ibu hamil, LILA, cloud

\begin{abstract}
Measurement of LILA in the group of women of childbearing age (WUS) both pregnant women is one of the ways of early detection that is easy and can be carried out by ordinary people, to find out groups at risk of KEK. KEK is a condition where mothers suffer from chronic food shortages that result in health problems for the mother. So far, the recording system for pregnant women in posyandu still uses a manual system, which is the data of pregnant women obtained using a calculator to determine the condition of pregnant women categories. In addition, the data used to carry out the data is still using books and Microsoft Excel. data on pregnant women and difficulties in reporting because the data is not properly stored. Data like this are very prone to data loss and data damage if a time is needed again. In this research, a website-based system that can display datatext and image data, both static and dynamic, forms a series of interrelated buildings where each is connected with a network of pages (hyperlink) with the storage media file files / documents from data work results that accommodate the capacity of cloud-based storage media and networks can be integrated and synchronized via the internet. This research has been successfully carried out that can store data in the cloud in the form of pregnant women data in the form of additional patient data, edit data, delete data and search data other than that on the website display can display login pages, dashboards, interpretation data, patient data pages, pages patient data calculation, patient data edit page.
\end{abstract}

Keywords: nutrition, pregnant women, LILA, cloud 


\section{Pendahuluan}

Sebagian besar ibu hamil mengalami lingkar lengan atas kurang dari batas normal. Berdasarkan data awal dari 15 ibu hamil ditemukan 10 ibu mengalami LILA kurang dari batas normal. 5 ibu mengalami LILA batas normal. Meskipun semua orang di Indonesia sudah mengetahui manfaat gizi bagi ibuhamil namun sampai saat ini masih banyak ibu hamil yang mengalami lingkar lengan atas kurang dari normal sebagai indikator gizi kurang seperti Kurang Energi Kronis (KEK).

Gizi ibu hamil adalah makanan atau zat-zat gizi yang di butuhkan oleh seorang ibu yang sedang hamil baik pada trimester I, trimester II, dan trimester III dan harus cukup jumlah dan mutunya dan harus di penuhi dari kebutuhan makan sehari-hari sehingga janin yang dikandungnya dapat tumbuh dengan baik serta tidak mengalami gangguan dan masalah [1]. Data BPS Kusmawati Surabaya menunjukkan bahwa ibu hamil atau Wanita Usia Subur (WUS) menderita lingkar lengan atas kurang dari batas normal, masalah ini mengakibatkan pada saat hamil akan menghambat pertumbuhan janin sehingga menimbulkan resiko pada bayi dengan BBLR [2]. Ukuran LILA yaitu : a) Pengertian Pengukuran LILA adalah suatu cara untuk mengetahui resiko Kekurangan Energi Protein (KEP) wanita usia subur (WUS). Pengukuran LILA tidak dapat digunakan untuk memantau perubahan status gizi dalam jangka pendek [3]. LILA merupakan salah satu pilihan untuk penentuan status gizi ibu hamil.

Pengukuran LILA pada kelompok wanita usia subur (WUS) baik ibu hamil merupakan salah satu cara deteksi dini yang mudah dan dapat dilaksanakan oleh masyarakat awam, untuk mengetahui kelompok beresiko KEK. KEK merupakan keadaan dimana ibu penderita kekurangan makanan yang berlangsung menahun (kronis) yang mengakibatkan timbulnya gangguan kesehatan pada ibu. b) Tujuan Beberapa tujuan pengukuran LILA adalah mencakup masalah WUS baik ibu hamil maupun calon ibu, dan masyarakat umum. 13 Adapun tujuan tersebut adalah: (1) Mengetahui resiko KEK WUS, baik ibu hamil maupun calon ibu, untuk menapis wanita yang mempunyai resiko melahirkan BBLR. (2) Meningkatkan perhatian dan kesadaran masyarakat agar lebih berperan dalam pencegahan dan penanggulangan KEK. (3) Mengembangkan gagasan baru di kalangan masyarakat dengan tujuan meningkatkan kesejahteraan ibu dan anak. (4) Mengarahkan pelayanan kesehatan pada kelompok sasaran WUS yang menderita KEK.

LiLA merupakan pengukuran status gizi yang lebih mudah dan praktis karena hanya menggunakan satu alat ukur yaitu pita pengukur LiLA. Namun, LiLA hanya dapat digunakan untuk keperluan skrining, tidak untuk pemantauan. Khusus pada wanita hamil, LiLA digunakan untuk mengetahui risiko KEK karena pada umumnya wanita Indonesia tidak mengetahui berat badan pralahir, sehingga IMT prahamil tidak dapat diukur. Pengukuran IMT membutuhkan 2 alat yaitu timbangan dan pengukur tinggi badan yang membutuhkan persyaratan tertentu yang harus dipenuhi seperti kalibrasi alat timbang serta lantai yang keras dan datar untuk pengukuran tinggi badan. Namun, IMT tidak dapat digunakan sebagai indikator KEK ibu hamil karena perubahan berat badan yang terjadi selama kehamilan. Oleh sebab itu, LiLA bermanfaat untuk pengukuran risiko KEK pada ibu hamil karena LiLA relatif stabil. Berikut ini gambar alat ukur LILA

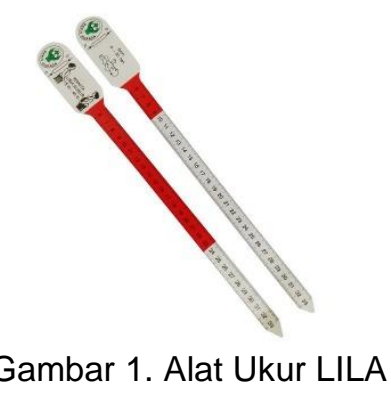

Cara Mengukur LILA Ada 7 urutan pengukuran LILA, yaitu : (1) Tetapkan posisi bahu dan siku (2) Letakkan pita antara bahu dan siku (3) Tentukan titik tengah lengan (4) Lingkarkan pita LILA pada tengah lengan (5) Pita jangan terlalu ketat (6) Pita jangan terlalu longgar (7) Cara pembacaan skala yang benar Pengukuran dilakukan di bagian tengah antara bahu dan siku lengan kiri (kecuali orang kidal kita ukur lengan kanan). Lengan harus dalam posisi bebas, lengan baju dan otot lengan dalam keadaan tidak tegang atau kencang. Alat pengukur dalam 
KOMPUTASI (Jurnal IImiah IImu Komputer dan Matematika)

Vol.16, No.1, Januari 2019, Hal. 235 - 244

P-ISSN: 1693-7554, E-ISSN: 2654-3990

https://journal.unpak.ac.id/index.php/komputasi

keadaan baik dalam arti tidak kusut atau sudah dilipat-lipat sehingga permukaannya sudah tidak rata.

Ukuran Lingkar Lengan Atas (LILA) Ibu hamil dan Kejadian Bayi Berat Badan Lahir Rendah(BBLR), bayi berat lahir rendah (BBLR) adalah bayi dengan berat lahir kurang dari 2500 gram tanpa memandang masa gestasi. Salah satu faktor yang mempengaruhi kejadian BBLR adalah status gizi ibu dimana status gizi ibu hamil dapat diukur menggunakan ukuran lingkar lengan atas (LILA). Penelitian ini bertujuan menguji dan mengestimasi hubungan antara ukuran Lingkar Lengan Atas (LILA) ibu hamil terhadap kejadian Bayi Berat Badan Lahir Rendah (BBLR). Penelitian ini bersifat analitik dengan pendekatan cross sectional. Jumlah Sampel sebanyak 30 orang pasien rawat jalan RSUD Dr. Moewardi Surakarta dipilih dengan teknik fixed disease sampling.Pengumpulan data dilakukan dengan 2 cara yaitu wawancara dan pengukuran langsung dengan pasien dan mencatat hasil rekam medis pasien. Data dianalisa dengan model analisis analisis regresi linier.Pengaruh LILA diukur dengan Odds Ratio (=OR) dan $\mathrm{Cl}$ 95\% Hasil penelitian menunjukkan lbu dengan lingkar lengan $<23.5 \mathrm{~cm}$ memiliki risiko 10 kali lebih besar untuk melahirkan bayi dengan berat badan rendah daripada ibu dengan lingkar lengan $>23.5 \mathrm{~cm}(\mathrm{OR}=10 ; \mathrm{Cl} 95 \%)$. Penelitian ini menyimpulkan bahwa ukuran lingkar lengan atas (LILA) $>23,5 \mathrm{~cm}$ akan menurunkan kejadian bayi berat badan lahir rendah(BBLR) yang secara statistic signifikan. Dokter dan profesional kesehatan diharapkan dapat menyediakan pendidikan dan penyuluhan kesehatan berkenaan dengan status gizi ibu hamil yang dapat mempengaruhi berat badan lahir bayi [4].

LILA merupakan gambaran tentang keadaan jaringan otot dan lapisan lemak bawah kulit. Pengukuran LILA dilakukan pada pertengahan antara pangkal lengan atas dan ujung siku dalam ukuran $\mathrm{cm}$ (centi meter) [5]. Cara pengukuran lila dapat dilihat dari langkah-langkah Pengukuran LILA berikut ini :

1. Tetapkan posisi bahu (acromion) dan siku (olecranon)

2. Letakkan pita pengukur antara bahu dan siku

3. Tentukan titik tengah lengan

4. Lingkaran pita LILA tepat pada titik tengah lengan

5. Pita jangan terlalu ketat, jangan pula terlalu longgar

6. Pembacaan skala yang tertera pada pita (dalam $\mathrm{cm}$ (centi meter)

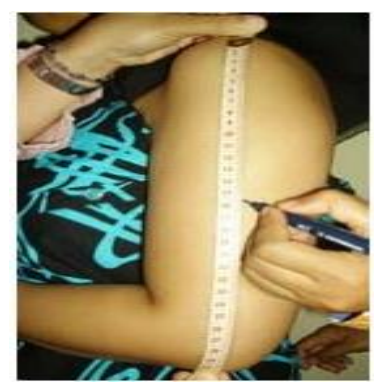

Gambar 2. Cara menentukan titik tengah untuk mengukur LILA

(Perhatikan lengan harus ditekuk 90 derajat)

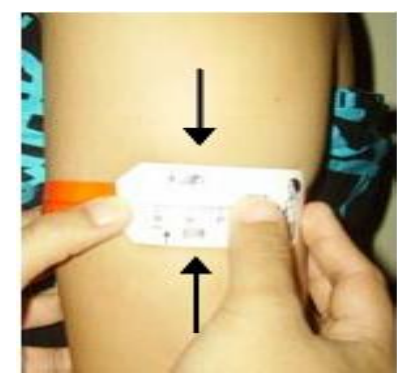

Gambar 3. Posisi tangan saat membaca LILA

(Tangan diluruskan setelah tadi ditekuk 90 derajat)

Pemantauan Kesehatan Gizi Ibu Hamil Dilihat dari Pertambahan Berat dan Pengukuran Lingkar Lengan Atas (LILA) Berbasis E-Digital (Yuli Wahyuni, Akbar Sugih Miftahul Huda) 
Keterangan :

Hasil pengukuran LILA kemudian diubah dalam bentuk persentase dengan standar:

Perempuan : $28,5 \mathrm{~cm}$

$$
\% \text { LILA }=\frac{\text { hasil LILA (Pengukuran) }}{\text { Standar Lila }} \times 100 \%
$$

Gambar 4. Rumus LILA

Tabel 1. Interpretasi status gizi berdasarkan \% \% LILA :

\begin{tabular}{|l|l|l|}
\hline No & Kategori & Nilai (\%) \\
\hline 1. & Obesitas & $>120 \%$ \\
\hline 2. & Overweight & $110-120 \%$ \\
\hline 3. & Normal & $90-110 \%$ \\
\hline 4. & Undeweight & $<90 \%$ \\
\hline
\end{tabular}

Contoh Kasus, Misal hasil pengukuran LILA Ny Vera adalah $26 \mathrm{~cm}$, Hasil persetase LILA $26 /$ Standar LILA perempuan $(28,5 \mathrm{~cm}) \times 100 \%=26 / 28,5 \times 100 \%=91,23 \%$, (Maka status gizi Ny Vera adalah NORMAL).

Contoh :

LILA $=26 \mathrm{~cm}$

Hasil persentase LILA adalah 26/Standar LILA perempuan $\times 100 \%$

$=26 / 28,5 \mathrm{~cm} \times 100 \%$

$=91,23 \%$

Maka Status Gizi Ny Vera adalah NORMAL.

Hasil perhitungan LILA akan dimasukan dalam Website sehingga terkumpul semua data Ibu Hamil dalam Website. Tapi, yang tersimpan dalam Website akan dimasukan atau Disimpan dalam Cloud.

Proses transfer data ke dalam Cloud disajikan sebagai berikut :

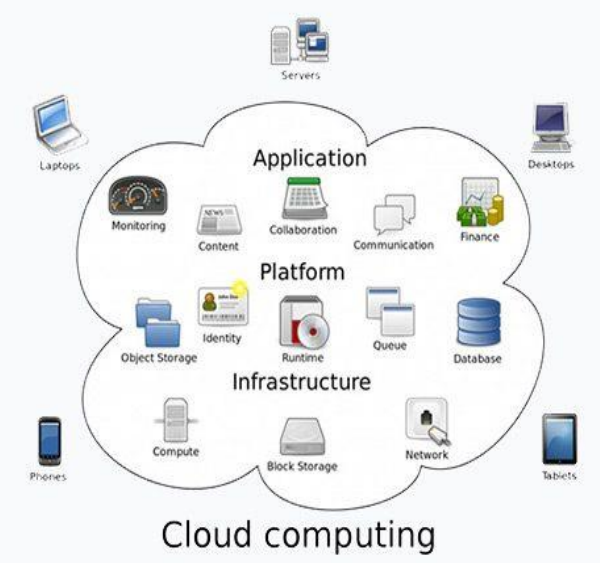

Gambar 5. Cloud Computing [6]

Keterangan mengenai pada gambar diatas :

1. Phones, Menurutnya definisi smartphone adalah telepon selular dengan menggunakan berbagai layanan seperti, memori, layar, mikroprosesor, dan modem bawaan. Sehingga fitur yang ada di smart phone ini terasa lebih lengkap di bandingkan dengan fitur hanphone lainnya [7].

2. Laptop, Adalah sebuah komputer bergerak yang dapat kita bawa kemanapun saja yang kita inginkan.Yang terdiri dari CPU,Monitor,Keyboard,Mouse dan juga sumber daya tenaga batery dapat dicas ulang dengan daya listrik.Baterai laptop umumnya berlangsung lebih kurang 1-6 jam sebelum dicas kembali, tergantung di penggunaan, spesifikasi, dan ukuran 
baterai. Laptop kadang-kadang juga dianggap personal komputer notebook atau notebook saja. Menjadi komputer langsung, laptop memiliki fungsi yang sama menggunakan personal komputer desktop (personal komputer desktop) pada umumnya. Komponen yang terkandung di dalamnya sama persis dengan komponen di desktop, hanya lebih kecil serta lebih banyak, membuat lebih ringan, lebih sedikit panas dan lebih hemat daya.

3. Server, adalah computer yang mendukung aplikasi dan telekomunikasi dalam jaringan, serta pembagian peralatan software, dan database di antara berbagai terminal kerja dalam jaringan.

4. Dekstop, adalah antarmuka pengguna (user interface) utama dari komputer. Ketika Anda menghidupkan komputer, desktop ditampilkan setelah proses startup selesai. Ini mencakup latar belakang desktop (atau wallpaper) dan ikon file dan folder Anda yang mungkin telah disimpan ke desktop.

5. Tablets, Sabak elektronik atau komputer tablet (bahasa Inggris: tablet computer), atau ringkasnya tablet, adalah suatu komputer portabel lengkap yang seluruhnya berupa layar sentuhdatar. Ciri pembeda utamanya adalah penggunaan layar sebagai peranti masukan dengan menggunakan stilus, pena digital, atau ujung jari, alih-alih menggunakan papan ketikatau tetikus. Microsoft memperkenalkan versi Windows XP untuk komputer tablet yang disebutnya Tablet PC pada tahun 2000, sedangkan Apple baru meluncurkan versi komputer tabletnya pada tahun 2010 dengan nama iPad. Pada tahun 2011 Samsung meluncurkan versi komputer tablet Galaxy Tab 7 (yang kemudian dilanjutkan dengan peluncuran Samsung Galaxy Tab 7.0 Plus) dan 10.1(P7100).

Network, Jaringan komputer (jaringan) adalah jaringan telekomunikasi yang memungkinkan antar komputer untuk saling berkomunikasi dengan bertukar data. Tujuan dari jaringan komputer adalah agar dapat mencapai tujuannya, setiap bagian dari jaringan komputer dapat meminta dan memberikan layanan (service). Pihak yang meminta/menerima layanan disebut klien (client) dan yang memberikan/mengirim layanan disebut peladen (server). Desain ini disebut dengan sistem client-server, dan digunakan pada hampir seluruh aplikasi jaringan komputer. Dua buah komputer yang masing-masing memiliki sebuah kartu jaringan, kemudian dihubungkan melalui kabel maupun nirkabel sebagai medium transmisi data, dan terdapat perangkat lunak sistem operasi jaringan akan membentuk sebuah jaringan komputer yang sederhana. Apabila ingin membuat jaringan komputer yang lebih luas lagi jangkauannya.

Situs web (bahasa Inggris: website) adalah suatu halaman web yang saling berhubungan yang umumnya berada pada peladen yang sama berisikan kumpulan informasi yang disediakan secara perorangan, kelompok, atau organisasi. Sebuah situs web biasanya ditempatkan setidaknya pada sebuah server web yang dapat diakses melalui jaringan seperti Internet, ataupun jaringan wilayah lokal (LAN) melalui alamat Internet yang dikenali sebagai URL [8].

Teknologi cloud computing merupakan salah satu pengembangan dariteknologi virtualisasi yang mendukung sebuah mesin komputer tunggal untukmembentuk duplikasi mesin secara virtual yang dapat berfungsi seperti mesin fisik. Salah satu jenis layanan cloud computing adalah Infrastructure as a Service yang didalamnya terdapat layanan penyediaan infrastruktur hardware seperti CPU virtual yang berisi RAM atau memory, processor dan disk storage, serta switch virtual. Dengan layanan infrastruktur tersebut maka dapat dikembangkan menjadi sebuah sistem cloud computing untuk penyediaan web server karena dapat mengasilkan beberapa mesin web server virtual sesuai dengan kebutuhan serta menghemat biaya penyediaan device. Untuk platform pembangunan cloud computing digunakan Eucalyptus karena dari segi arsitekturn sistem yang dimiliki Eucalyptus dapat digunakan untuk area private maupun public dan mendukung client untuk memodifikasi web server virtual serta memiliki stuktur yang elastis yang menghubungkan server cloud dengan client [9].

Cloud computing merupakan pengembangan dari teknologi virtualisasi yang mendukung sebuah mesin komputer tunggal membentuk duplikasi mesin secara maya yang dapat berfungsi 
seperti mesin fisik. Kemudian dalam perkembangan pemenuhan kebutuhan akses sumber daya, mesin-mesin tersebut dirangkai dalam sebuah sistem yang dapat dengan mudah diakses dari jarak jauh [10]. Infrastructure as a Service atau laaS adalah salah satu dari tiga macam lapisan cloud computing yang mendistribusikan sistem pemberkasan standard dan kemampuan komputasi sebagai layanan terstandarisasi dalam jaringan. Server, sistem pemberkasan, switch, router dan sistem lain digabungkan dalam sebuah pool dan dibuat agar dapat diakses untuk mengurusi beban kerja yang terjadi dalam komponen aplikasi sampai pada aplikasi berkomputasi level tinggi [11]. Private cloud adalah salah satu dari deployment model cloud computing, yang infranstrukturnya mendukung dan khusus untuk sebuah perusahaan atau organisasi [12].

Perkembangan teknologi yang semakin pesat terutama yang berbasis website dengan menampilkan datatext, datagambar, diam atau gerak, data animasi, suara, video dan gabungan dari semuanya, baik bersifat statis maupun dinamis yang membentuk suatu rangkaian bangunan yang saling terkait dimana masing-masing dihubungkan dengan jaringan-jaringan halaman (hyperlink). Media penyimpanan file berkas/dokumen dari data hasil pekerjaan yang menampung kapasitas media penyimpanan pada zaman sekarang ini berbasis Cloud.

Cloud penggunaannya melalui perantara jaringan yang terintegrasi dan tersinkronisasi melalui internet yang dapat dihubungkan dengan aplikasi berbasis Website. Selama ini system pencatatan ibu hamil di posyandu kuntum mekar jalan ciheuleut masih menggunakan system manual yaitu data ibu hamil yang diperoleh masih menggunakan kalkulator untuk mengetahui kondisi kategori ibu hamil selain itu data yang digunakn untuk mengarsif data masih menggunakan buku dan Microsoft excel hal ini sangat menyulitkan petugas posyandu apabila mau mencari data ibu hamil dan kesulitan dalam melakukan laporan karena data tidak disimpan dengan baik. Data seperti ini sangat rawan kehilangan data dan kerusakan data apabila suatu waktu dibutuhkan lagi.

Mengacu dari permasalahan diatas betapa pentingnya pengukuran LiLA dengan menggunakan teknologi dengan media penyimpanan berbasis Website dan Cloud maka perlu dibuat website cara menghitung LiLA berbasis Website dan Cloud.

\section{Metode Penelitian}

Metode penelitian yang diterapkan pada penelitian berjudul aplikasi berbasis Web yang dapat menghitung LILA seorang Ibu Hamil dengan menggunakan teknologi Cloud.yaitu dengan menggunakan metode Siklus Hidup Pengembangan Sistem (System Development Life Cycle/ SDLC). Tahap yang dilakukan secara umum dalam pengembangan sistem berdasarkan Siklus Hidup Pengembangan Sistem (System Development Life Cycle/ SDLC) terdiri dari 5 tahap: Tahap Perencanaan, Tahap Analisis Sistem, Tahap Perancangan, Tahap Implementasi dan Tahap Uji Coba, pengembangan sistem SDLC dapat dilihat pada Gambar 6:

\subsection{Perencanaan Sistem}

Pada tahap perencanaan dilakukan pengumpulan data dan menentukan bagaimana sistem dapat membantu menyelesaikan permasalahan yang ada. Tahap perencanaan ini dilakukan berdasarkan pada studi kepustakaan dan studi lapangan. Studi kepustakaan dilakukan dengan cara mempelajari buku-buku dan dokumen yang berupa hardcopy maupun softcopy mengenai pengukuran LILA ibu hamil. Studi Lapangan dilakukan untuk melakukan pengumpulan data untuk pembuatan aplikasi, diantaranya Observasi (Pengamatan) dan Wawancara.

\subsection{Analisis Sistem}

Tahap analisis sistem dilakukan untuk mendefinisikan kebutukan-kebutuhan pada aplikasi. Tujuan analisis ini adalah agar lebih memahami tentang aplikasi yang akan dikembangkan berdasarkan masukan dari Kepala Seksi Data Serta pengumpulan informasi yang dibutuhkan berupa dokumen-dokumen mengenai surat pengadaan langsung sebagai data yang dibutuhkan dalam pembuatan aplikasi. 


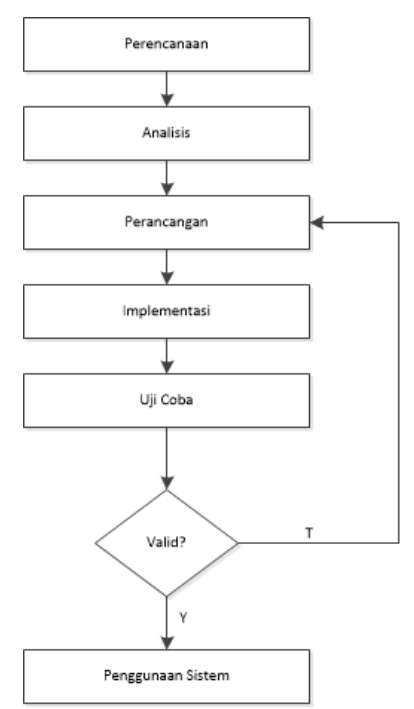

Gambar 6. System Development Life Cycle (SDLC)

\subsection{Perancangan Sistem}

Tahap perencanaan sistem adalah tahap persiapan spesifikasi sistem yang akan dibangun. Perencangan Sistem Informasi Perpustakaan ini dibagi menjadi 3 bagian yaitu perancangan database perancangan alur kerja sistem dan perancangan iput dan output. Perancangan database dilakukan menggunakan class diagram. Perancangan alur kerja sistem menggunakan flowchart.

\subsection{Implementasi Sistem}

Pada tahapan implementasi ini merupakan tahap dimana perancangan sistem yang telah dibuat diimplementasikan dengan menggunakan program tertentu. Pada tahap ini dilakukan penerapan hasil rancangan yang terarah dibuat ke dalam bentuk pengimplementasian sebuah program aplikasi yang dibuat dengan Bahasa pemrograman PHP. PHP merupakan bahasa scripting yang tergabung menjadi satu dengan HTML dan dijalankan pada server side atau semua perintah yang diberikan akan secara penuh dijalankan pada server, sedangkan yang dikirimkan ke klien (browser) hanya berupa hasilnya saja [13], [14]. berbasis framework Code Igniter. Codelgniter adalah sebuah framework PHP yang dapat membantu mempercepat developer dalam pengembangan aplikasi web berbasis PHP [15]. Database yang digunakan MySQL dan design yang menggunakan Bootstrap [16], [17]. Untuk uji coba aplikasi menggunakan browser Chrome dan Xampp sebagai server host.

\subsection{Uji Coba Sistem}

Tahap ini merupakan tahap untuk mengetahui apakah seluruh sistem yang telah diimplementasikan berjalan dengan baik atau tidak, tahap uji coba (validasi) ini dilakukan untuk melihat konsistensi dan kehandalan sistem yang sudah di rancang tersebut berjalan sesuai rancangan yanga dibuat atau tidak. Apabila masih terdapat kekurangan atau kesalahan, maka sistem yang telah dibuat harus dilakukan evaluasi agar berjalan dengan kebutuhan pengguna dan kebutuhan sistem. Uji coba ini meluputi tahapan dibawah ini :

1. Uji Coba Struktural

2. Uji Coba Fungsional

3. Uji Coba Validasi

\section{Hasil dan Pembahasan}

Dalam hasil dan pembahasan dalam penelitian ini didapat hasil-hasil berupa tampilan aplikasi berbasis website yaitu : halaman login, halaman dashboard, halaman data interprestasi, halaman data pasien, halaman tambah data pasien dan halaman edit data pasien. 


\subsection{Halaman Login}

Halaman ini digunakan staff dan administrator selain untuk masuk kedalam sistem informasi manajemen, halaman ini juga berguna sebagai keamaan sistem administrator agar tidak sembarang orang dapat mengakses dan merubah data-data yang ada dalam sistem. Karena halaman login ini menyediakan hanya menyediakan hak akses untuk petugas. Ketika halaman ini diakses dengan username atau password yang salah maka sistem akan memberikan peringatan.

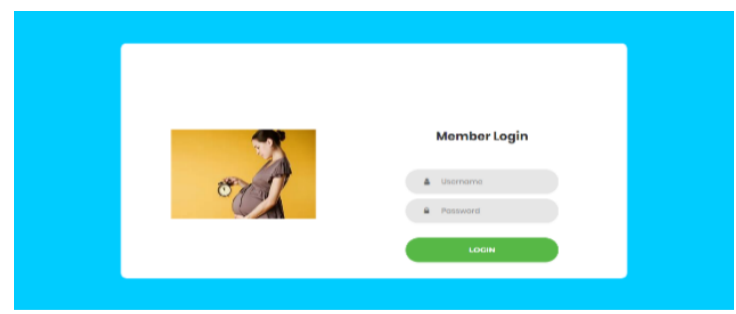

Gambar 6. Halaman Login

\subsection{Halaman Dashboard}

Halaman ini merupakan halaman yang akan dilihat oleh petugas setelah berhasil melakukan proses login. Dibawah header terdapat menu navigasi yang merupakan menu utama. Untuk lebih lengkapnya dapat dilihat pada gambar dibawah ini.

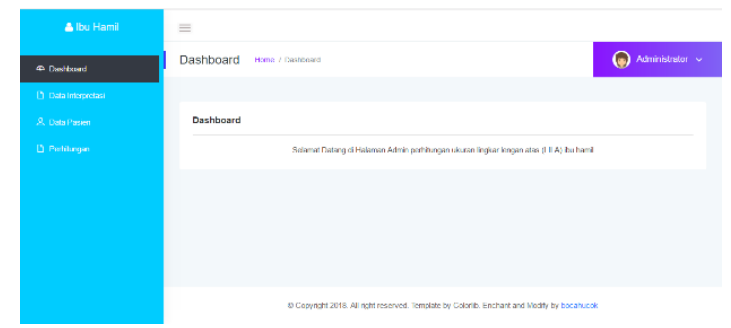

Gambar 7. Halaman Dashboard

\subsection{Halaman Data Interpretasi}

Halaman ini digunakan petugas untuk melihat, menambah, meng-edit, dan menghapus data pasien yang telah dibuat untuk lebih lengkapnya dapat dilihat pada gambar dibawah ini.

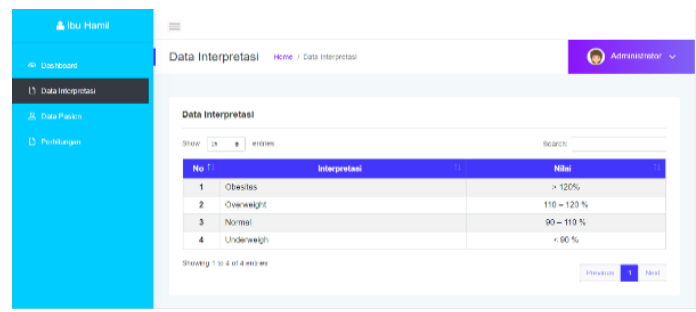

Gambar 8. Halaman Data Interpretasi

\subsection{Halaman Data Pasien}

Halaman ini digunakan petugas untuk melihat, menambah, meng-edit, dan menghapus data pasien yang telah dibuatUntuk lebih lengkapnya dapat dilihat pada gambar dibawah ini.

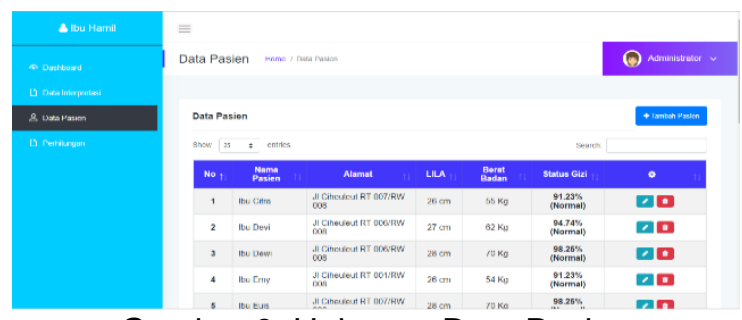

Gambar 9. Halaman Data Pasien 
KOMPUTASI (Jurnal IImiah IImu Komputer dan Matematika)

Vol.16, No.1, Januari 2019, Hal. 235 - 244

P-ISSN: 1693-7554, E-ISSN: 2654-3990

https://journal.unpak.ac.id/index.php/komputasi

\subsection{Halaman Tambah Data Pasien}

Halaman ini digunakan petugas untuk melihat, menambah, meng-edit, dan menghapus data pasien yang telah dibuatUntuk lebih lengkapnya dapat dilihat pada gambar dibawah ini.

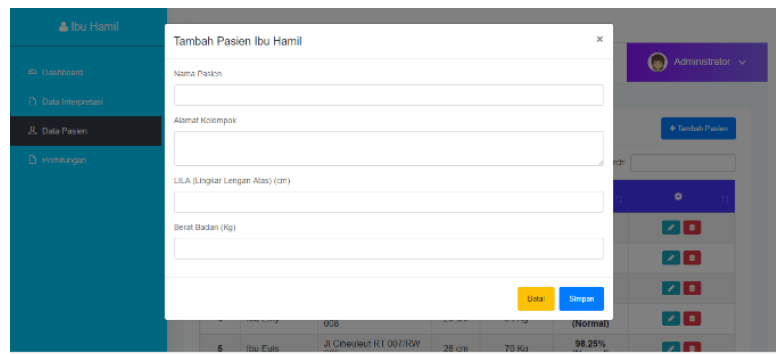

Gambar 10. Halaman Perhitungan data pasien

\subsection{Halaman Edit Data Pasien}

Halaman ini digunakan petugas untuk melihat, menambah, meng-edit, dan menghapus data pasien yang telah dibuatUntuk lebih lengkapnya dapat dilihat pada gambar dibawah ini.

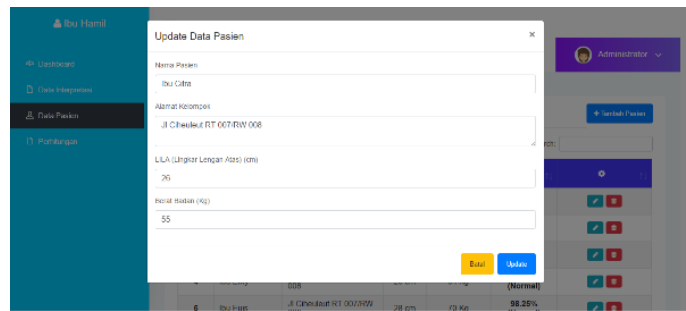

Gambar 11. Halaman edit data pasien

\section{Kesimpulan}

Sistem Informasi ini dibangun dengan menggunakan bahasa pemrograman PHP versi 7 berbasis Framework Code Igniter dan MySQL sebagai database. Metode yang digunakan dalam pembangunan aplikasi ini adalah metode SDLC yang didalamnya terdapat langkahlangkah yaitu: perencanaan, analisis, perancangan, implementasi, uji coba dan penggunaan. Sistem Informasi ini telah diujicoba dengan beberapa tahap yaitu uji coba struktural, uji coba validasi, uji coba fungsional. Sistem Informasi pengukuran LILA ibu hamil jalan ini memiliki fungsi/fitur antara lain halaman login, halaman dashboard, halaman data interprestasi, halaman data pasien, halaman tambah data pasien dan halaman edit data pasien. Aplikasi ini berbasis Web yang dapat menghitung LiLA seorang lbu Hamil dengan menggunakan teknologi Cloud. Teknologi cloude digunakan untuk pendatabasean laporan per periode ukuran LILA ibu hamil, hasil pengujian teknologi cloude telah diuji dalam bentuk pengujian data pasien, data interpresta dan data standar selain itu telah dilakukan uji coba dibeberapa browser yaitu broser opera, mozila dan chrome. Sistem ini juga telah melewati proses uji coba antara lain uji coba struktural, uji coba fungsional, dan juga uji coba validasi.

\section{Referensi}

[1] W. KRISTIYANASARI, Gizi Ibu Hamil. Yogyakarta: Nuha Medika, 2016.

[2] Z. R. and Joeharno, "Pathway BBLR (Berat Badan Lahir Rendah)," 2006. [Online]. Dapat diakses di: https://blogjoeharno.blogspot.com/2008/05/berat-badan-lahir-rendahbblr.html. [Diakses: 20-Apr-2013].

[3] I. D. N. Supariasa, B. Bakri, and I. Fajar, Penilaian Status Gizi, Edisi kedu. Jakarta: EGC, 2016.

[4] Y. B. Adhi, Ukuran Lingkar Lengan Atas (LILA) Ibu Hamil dan Kejadian Bayi Berat Badan Lahir Rendah (BBLR). 2010.

[5] F. J. Zeman and D. M. Ney, Applications of Clinical Nutrition. Pearson College Div, 1988.

Pemantauan Kesehatan Gizi Ibu Hamil Dilihat dari Pertambahan Berat dan Pengukuran Lingkar Lengan Atas (LILA) Berbasis E-Digital (Yuli Wahyuni, Akbar Sugih Miftahul Huda) 
[6] U. D. Arni, "Karakteristik Cloud Computing," Computing, 2011. [Online]. Dapat diakses di: https://garudacyber.co.id/artikel/1453-karakteristik-cloud-computing. [Diakses: 05May-2019].

[7] B. K. Williams and S. C. Sawyer, Using information technology a practical introduction to computers \& communications: Complete version, 9th ed. New York: NY McGraw-Hill, 2011.

[8] Sutarman, Membangun aplikasi web dengan PHP dan MySQL. Yogyakarta: Graha IImu, 2009.

[9] W. Kim, "Cloud computing architecture," Int. J. Web Grid Serv., vol. 9, no. 3, pp. 287303, 2013.

[10] K. Rabah, Build Your Own Private Cloud Using Ubuntu 10.04 Eucalyptus Enterprise Cloud Computing Platform, First Edit. Vancouver Canada: Global Open Versity, 2013.

[11] M. Sharma, "Cloud Computing Architecture\& Services," IOSR J. Comput. Eng., vol. 19, no. 02, pp. 13-18, 2017.

[12] J. Hurwitz, R. Bloor, M. Kaufman, and F. Halper, Cloud Computing For Dummies. 2010.

[13] A. P. Widodo, "Pemrogram WEB Jeda." [Online]. Dapat diakses di: https://www.scribd.com/doc/11382213/Pemrogram-WEB-Jeda. [Diakses: 05-May-2019].

[14] Anhar, Panduan Menguasai PHP dan MySQL secara Otodidak. Jakarta: MediaKita, 2010.

[15] A. P. Basuki, Membangun Web Berbasis PHP Dgn Framework Codelgniter. Lokomedia, PT, 2010.

[16] K. Abdul, Dasar pemrograman Java 2. Yogyakarta: Andi, 2005.

[17] S. Pahlevi, tujuh langkah praktis pembangunan basis data. 2013. 